\title{
Singapore Country Assistance to Help Extinguish Forest Fire in South Sumatera
}

\author{
Anton Minardi*, Taufik, Dewi Astuti, Mochammad Irvan Pamungkas \\ International Relations Department Pasundan University \\ *Corresponding Author: abdurrahmananton1975@gmail.com
}

\begin{tabular}{llll} 
Article history & & \\
\hline Received & Received in revised form & Accepted & Available online \\
29 September 2019 & 30 March 2020 & 31 March 2020 & 31 March 2020 \\
\hline
\end{tabular}

Abstract: Forest and land fires has become one of the most difficult natural disaster to handle, forest and land fires happened every year all around the world, and become one of the many cause of global warming and climate change and if it is not resolved immediately then it will harm all of the living beings on this earth. Forest and land fire in Indonesia happened nearly every year, the first biggest forest and land fires ever recorded in Indonesia happened in 1998-1999 which harm many parties, especially the ASEAN, since then, forest and land fires in Indonesia nearly happened every year whose impact neighboring countries like Singapore and Malaysia, In 2015 forest and land fires can be said quite large and once again affects neighboring countries, until Indonesia neighboring countries like Singapore want to try to help extinguish the forest and land fires in Indonesia.

Keywords: Forest and Land Fires, Global Warming, Climate Change, Singapore Assistance, South Sumatera.

\section{Introduction}

According to Notohadinegoro, forest fires are something that burns that creates danger or causes disaster. Fires can occur due to uncontrolled combustion, due to a natural spontaneous process, or because of intent. Natural processes such as lightning striking trees or buildings, volcanic eruptions that scatter chunks of fire, and friction between dry branches of plants that contain oil due to wind shaking that causes heat or sparks of fire [1].

ASEAN, as an International Organization with member countries that have large areas of dense forest, is not uncommon to experience forest and land fire disasters, forest and land fires will cause smoke or smog. In 2014, a number of ASEAN countries were recorded as experiencing forest and land fire disasters such as Vietnam, Malaysia, Thailand, Cambodia, Laos and Indonesia [2].

In Indonesia, 99\% of forest and land fires are caused by human activities, such as habits and behavior, the need for land for settlements and agriculture or plantations (forests are cleared by burning because they are faster, easier and cheaper), land conflicts, and accidental or other activities which causes fire such as the search for firewood, grass, rattan, honey, fish, camping, burning trash, and many other causes caused by humans [3].

According to data released by SiPongi (the Indonesian Ministry of Environment and Forestry's forest and land fire monitoring application) said that in the past 6 years, forest and land fires that occurred at several points in Indonesia's forest areas are increasing and decreasing, which in 2015 is the worst year in the area of forest and land fires, which is around $261,060.44$ hectares of land and forests in Indonesia burned, with a total from 2013 to 2018 land and forest fires that occurred in Indonesia reached 340,789.26 hectares, of course this number is not a small amount [4].

Forest fires that cause haze are also exacerbated by the presence of El-Nino factors and climate change. El-Nino is a natural phenomenon that causes a long dry season in an area, the absence of rainfall and also a long dry season that makes forestry and plantation areas dry and flammable [5].

Forest and land fires in Indonesia are now seen as regional and global disasters. This is caused by the impact of forest fires that have spread to neighboring countries and the gases resulting from combustion emitted into the atmosphere (such as $\mathrm{CO} 2$ ) have the potential to cause global warming [6].

One of the countries seriously affected by the smoke haze that occurred in Indonesia is the State of Singapore, where forest fires that occurred in the islands of Sumatra, the Republic of Indonesia, caused huge clouds of smoke and then the smoke was carried up to Singapore, causing various losses experienced by the State of Singapore.

With the impact felt by the State of Singapore and Singapore's commitment to dealing with climate change and global warming, Singapore also 
contributed to helping Indonesia to extinguish forest and land fires in South Sumatra in 2015.

\section{Method}

The research method that the author will use in this research is a qualitative case study method, the main purpose of qualitative research is to understand (to understand) social phenomena or phenomena by focusing more on the complete picture of the phenomenon being studied rather than detailing it into variables interrelated. The hope is to obtain a deep understanding of the phenomenon to further produce a theory. The case study research method is an in-depth study of individuals, one group, one organization, one program of activities, and so on within a certain time. The goal is to obtain a complete and deep description of an entity. Case studies produce data for analysis later on to produce theories. As with qualitative research data acquisition procedures, case study data were obtained from interviews, observations, and archives.

Using this research method, the author will describe a condition in which Singapore's assistance to Indonesia in the case of forest fires that occurred in South Sumatra is Singapore's active attitude in handling environmental damage, especially those that cause global climate change. The author will also analyze the extent of the role and results of these assistance in handling cases of forest fires that occurred in Indonesia.

\subsection{Theoretical Framework}

In international relations there is a new thought or paradigm called green politics, green thinking is a thought that starts from the basic assumption that humans and nature have a relationship that ultimately causes these environmental crises. In fact, activists who care about the environment argue that human habits in the modern era are the main causes of the environmental crisis [7]. that is:

Green Thought has some basic assumptions, and

1. Environmentalists emphasize Global interests above International;

2. This perspective departs from the implicit understanding that current human habits are no longer in line with the non-human world in some sense;

3. There is an emphasis that human habits in modern times, supported by anthropocentric belief systems, are the main cause of environmental crises [7].

Green Thought assume that there is a significant relationship between human actions on the environment and the destruction of the environment itself. Green Thought also offers a wholistic perspective that can see how closely the relationship between human life and the global ecosystem, in essence is emphasizing the need to preserve the environment for the survival of all living things [8].

With Green Thought thinking it can be concluded that the environmental damage that occurs in the world is due to human activities that are anthropocentrism, anthropocentrism is an understanding where humans are the most central species and more important than other species (animals and plants). Anthropocentrism has occurred in various parts of the world with a lot of environmental damage, one of which is forest fires.

Forest and peatland fires are surface fires where the fire burns fuel on the surface (for example: litter, trees, bushes, etc.), which then spreads erratically slowly beneath the surface (Ground Fire), burning organic material through pores - peat pores and through the roots of shrubs or trees with burnt tops. During its development, the fire spread vertically and horizontally shaped like a smoke bag with unburned combustion (Smoldering) so that only white smoke that appears above the surface [9].

Forest fires that occur continuously will produce a lot of $\mathrm{CO} 2$ chemical compounds that can damage the earth's ozone layer, carbon dioxide is produced by smog caused by forest fires and will greatly affect global warming, as explained by Nina Yulianti:

$\mathrm{CO} 2$ fire emissions are an important source of atmospheric $\mathrm{CO} 2$ and contribute substantially to the global greenhouse effect. $\mathrm{CO} 2$ is a colorless, odorless and mild acid gas. Carbon dioxide is also called carbon acid gas, often called mixed air. Although this amount of gas is a very small part of all the gases in the atmosphere (only about $0.04 \%$ on a natural molar basis), it has an important role in supporting life. If its unbalanced existence will create natural phenomena that are capable of damaging the earth such as perforating the ozone layer, the greenhouse effect, sunlight \& heat entering the earth cannot be cosmically released into space, increasing the global temperature by several degrees so that it can melt ice poles thus increasing sea level [10].

Global warming has become a concern of all countries in the world, because global warming has many negative impacts on survival on earth, according to the Inter-governmental Panel on Climate Change (IPCC) as quoted from the National Geographic page, that if the rate of global warming is not drastically reduced, climate risks for human well-being, ecosystems and sustainable development, will rise to 
dangerous levels and have a permanent impact. IPCC explained, global warming since preindustrial times has exceeded one degree centigrade. At the current level of greenhouse gas emissions, the rate of global warming will reach 1.5 degrees celsius in the next few decades. If the temperature rises again to two degrees Celsius, it will increase natural disasters, accelerate the melting of Arctic sea ice, cause islands to sink, and the inability to produce food for the world's population continues to grow [11].

\section{Results and Discussion}

Indonesia was once called as the world's lungs along with amazon forests because of the vast forest area it has, but it seems that the nickname is gradually fading because of the large amount of deforestation and forest and land fires that occur in Indonesia, if left unchecked, then the entire forest area in Indonesia could be lost because of the rampant deforestation and forest burning.

Green Politics is a new paradigm in the science of International Relations that prioritizes environmental safety on earth, and believes that world peace can be achieved in this way, green politics strongly emphasizes environmental sustainability because one of the keys of green politics is ecosentrism, ecocentrism rests on natural balance and has four characteristics, namely resource conservation, ecology of human well-being, maintenance that takes into account the future of human and non-human generations, and the release of animals that pay attention to environmental factors, with forest fires that occurred in South Sumatra in 2015, of course this is not in line with the green political view not to do something that can damage the balance of nature because large-scale forest fires can disrupt many things, such as ecosystems, both the forest ecosystem itself, and ecosystems outside the forest, and then can have a negative impact. Truk on the surrounding environment, on a large scale, the adverse effects can be felt by countries that are located close to Indonesia, one of which is Singapore.

Forest and land fires also become a global threat, because the resulting haze can cause depletion of the ozone layer in the atmosphere, although it is not the only cause of ozone depletion, but the smog also has an influence on the overall depletion of the ozone layer, forest and land fires overall in Indonesia in 2015 contributed to an increase in the concentration of emissions in Indonesia.

\subsection{Singapore's concern for global climate change}

One of NASA researchers (National Aeronautics and Space Administration), Steve Nerem said, as reported by the news portal DW (Deutshce Welle), if global warming continues to occur and increase sea level, then a number of large cities and even countries that have land heights which is close to sea level will disappear from the surface of the earth due to sinking, one of the countries that will be affected is Singapore [12]. although this impact will not occur in the near future, but this threat is a real threat and will occur if it is not taken seriously by the States in the world. For these reasons Singapore has a commitment to global climate change, by signing international agreements relating to world climate change.

\subsubsection{Singapore Involvement in the ASEAN Agreement on Transboundary Haze Pollution}

The purpose of AATHP itself is "to prevent and supervise cross-border smoke pollution as a result of forest or land fires that must be mitigated, through joint national efforts and regional and international cooperation", then to realize the objectives of the AATHP itself, in Singapore there is already a Singapore's ASEAN Specialized Meteorological Center which helps record hotspots and smoke movements, also provides periodic predictions about weather conditions throughout the region.

\subsubsection{Singapore Invovement in the Kyoto Protocol}

Singapore has also ratified one of the amendments to the United Nations framework on environmental issues, namely the Kyoto Protocol, more fully, the Kyoto Protocol is an amendment to the United Nations framework convention on climate change, an international agreement on global warming. The main mission of the Kyoto Protocol is to reduce emissions / emissions of carbon dioxide and five other greenhouse gases, or work together in the emissions trade if they maintain the amount or increase the emissions of these gases, which have been linked to global warming.

\subsubsection{Singapore's Declaration on Climate change, Energy and the environment at The Third East Asia Summit (EAS)}

The declaration which was held in Singapore on November 21, 2007 contains how heads of ASEAN countries, Australia, China, India, Japan, the Republic of Korea and also New Zealand, expressed their concern about the impact caused by global warming on social economic development, health, and as well as the environment, especially those in developing 
countries, thus stressing the need to increase their adaptation capacity, as well as for the international community to expedite action on the development of global greenhouse emissions.

The agreements that have been ratified and also the declarations that have been submitted by Singapore are a sign of how Singapore has a concern for the environment and also the stability of the world climate, because the State of Singapore can be said to be one of the countries that will be affected by a significant amount of haze caused by by forest fires and climate change and global warming.

\subsection{Forest and land fires in South Sumatra and their causes}

In the Green Politics paradigm, there are three main keys that make this paradigm a new paradigm that is different from other existing paradigms. power, ecology of human well-being, care for the future of human and non-human generations, and release of animals that pay attention to environmental factors. Looking at it from this perspective, Singapore has adopted one of the four characteristics of green political ecocentrism, namely maintenance that takes into account the future of human and non-human generations, because with Singapore's involvement and activeness in helping to deal with the problem of forest fires that occur in Indonesia, Singapore is directly help the future survival of generations of people and nonhumans which if not addressed quickly and seriously can damage the ecosystems that exist on land, air and sea, and will also greatly affect the world ozone layer, due to the $\mathrm{CO} 2$ content caused by forest fires and land in Indonesia can be considered quite significant.

To illustrate how large the forest and land fires that occurred in southern Sumatra in 2015, data and facts will be presented related to the extent of forest and land fires in southern Sumatra, economic losses and also the resulting disease.

Greenpeace said that forest and land fires that occurred in Indonesia in 2015 were the largest environmental crime in the 21st century, due to the magnitude of forest fires that occurred and how the negative impact on health, the economy and environmental damage caused.

\subsection{The area of forest and peatland fire in Southern Sumatera in 2015}

In 2015, forest and land fires in Indonesia were recorded at 2,611,411.44 hectares, and in southern Sumatra, forest and land fires were recorded at $646,298.80$ hectares that were burning, forest and land fires in South Sumatra were the largest among other provinces in Indonesia, with 24 percent of forest and land fires occurring in Indonesia originating from South Sumatra.

\subsection{Economical Impact because of forest and peatland fire in Southern Sumatra in 2015}

Forest fires in Indonesia in 2015 also caused substantial economic losses, these forest fires caused economic losses of 221 trillion rupiah, or equivalent to 1.9 percent of Indonesia's Gross Domestic Product (GDP) [13].

Forest and land fires that occurred in South Sumatra accounted for 53.8 trillion rupiahs out of a total 221 trillion rupiahs economic losses arising from overall economic losses arising from forest and land fires, or around 24 percent of all losses suffered by Indonesia due to forest fires and land that occurred, forest fires and this land [13].

\subsection{Illnes because of forest and peatland fire in south Sumatra in 2015}

There are several impacts that will occur if humans inhale too much haze from forest and land fires according to Tjandra Yoga Aditama Head of Health Research and Development Agency (Balitbangkes) Ministry of Health, Republic of Indonesia, As reported by the news site Liputan 6, the adverse effects that will occur if humans inhale too much and live in areas affected by haze, namely: First, Immediate impact

a. Pulmonary and respiratory tract infections. Haze can cause local / local irritation of the mucous membranes in the nose, mouth and throat that are directly affected by forest fires, and cause allergic reactions, inflammation and possibly infection, starting ARI and if severe can get to pneumonia. The ability of the lungs and respiratory tract to cope with infection is also reduced, making it easier for infections to occur. Acute Respiratory Infection (ARI) becomes easier to occur, mainly due to imbalance of the immune system (host), patterns of bacteria / viruses etc. that cause disease (agents) and poor environment (environment). So, ARI in forest fires (the most talked about) occurs through 3 mechanisms, namely:

- Irritation

- Infection

- Decreased immune system to fight germs / viruses.

b. Eyes \& Skin, which is immediately exposed to smoke. Similar irritation disorders can also occur in the eyes and skin, which are directly in contact with smoke from forest fires, causing itching, 
watery eyes, inflammation and worsening infections.

c. Impact of smoke haze can worsen asthma and other chronic lung diseases, such as chronic bronchitis, COPD (chronic obstructive pulmonary disease) and others, because the smoke from forest fires will be inhaled into the lungs. The ability of the lungs to work becomes reduced and causes people to get tired easily and have difficulty breathing. The Center Hotel

Second, Indirect impacts

a. Pollutants in forest fire fumes that fall to the surface of the earth may also be a source of pollutants in clean water and unprotected food facilities. If then the water and contaminated food is consumed by the community, it is not impossible that gastrointestinal disorders and other diseases will not occur.

b. In general, various chronic diseases in various organs of the body (heart, liver, kidneys, etc.) can also worsen. This is partly due to the indirect effect where the smog decreases the body's resistance and also causes stress. It is stressed once again that those who are elderly and children (also those who have chronic disease) with low endurance will be more vulnerable to health problems. Health workers in the regions are certainly ready to anticipate the possibility of existing health problem.

\subsection{Number of complaints of illness due to poor air quality in South Sumatra in 2015}

The thick smoke haze caused by forest and land fires causes poor air quality in South Sumatra, ISPU recorded in Palembang on October 192015 reached 1,180 micrograms per cubic meter [14], while the healthy limit of air quality is at number $51-100$, this is the cause of the many ARI complaints suffered by residents who are exposed to haze in South Sumatra.

It has been explained that 99 percent of forest and land fires are caused by human activity, whether intentional or unintentional, not least with what happened with forest and land fires in South Sumatra in 2015, the police have arrested around 140 perpetrators of forest and land burners in South Sumatra, and 7 of them are large companies, the 8 actors are Sinar Mas Subsidiaries, 11 Wilmar Subsidiaries, 4 Sampoerna Subsidiaries, 3 PTPN Subsidiaries, Sime Darby, Cargill, Marubeni, and the rest are 133 residents local who want to open land for agriculture and plantations.
3.7. Singapore contribution in helping extinguish forest and fire burning in south Sumatra in 2015

With the impact of forest and land fires that are very large, Singapore also participated in helping to deal with forest fires in South Sumatra in several ways, namely :

a. Helicopter and Bambi Bucket Help

Singapore took action to assist Indonesia by sending a $\mathrm{CH} 47$ Chinook TMT helicopter with 40 personnel in it and a bambi bucket capable of carrying 5,000 liters of water, then Singapore would also dispatch a C-130 Hercules aircraft with 42 firefighters from the Civil Defense Agency Singapore (SCDF), along with the crew and equipment [15] for 13 days on 11 to 23 October 2015.

The helicopter sent by Singapore is the $\mathrm{CH} 47$ Chinook TMT helicopter that has been paired with a Bambi Bucket, where this type of helicopter is indeed dedicated to transporting troops, ammunition, materials, equipment, and war equipment, and this helicopter can also be used for medical evacuation, rescue missions of crashed aircraft, fire fighting, and other non-military work. Meanwhile, Bambi Bucket is a device made specifically for carrying large amounts of water and will later be dropped at the point of fire, this technique is called the water bombing technique, this technique is expected to extinguish forest and land fires efficiently and is also expected to neutralize smog, because the water bombing technique is almost the same as creating artificial rain at certain points.

There are several ways the State of Singapore to help put out fires that occurred in South Sumatra by helicopter and also the fleet it carries, As reported by the Indonesian ACT (Quick Response Response) Website. The first is to extinguish forest fires with water bombing technique. A bambi bucket that has been paired in a Singapore chinook helicopter will fly and will be filled from the sea, take sea water from the Bangka strait, then the helicopter will fly in the designated area, namely the Ogan Komering Ilir and Musi Banyuasin areas, then the existing water in the bambi bucket will be dropped on the hot spot that burned the area. Furthermore, Singapore helicopters will help map out hotspots and sources of water that can be used to extinguish, the Singapore Military Army fielded a chinook double-propelled helicopter [16], which will see wherever the hotspot is and map it , then determine which hotspot must first be extinguished.

b. Singapore delivering assistance from Singapore

Civil Defense Agency personnel to Indonesia

In addition to sending helicopter assistance, the Singapore state also sent a Hercules C-130 aircraft 
containing 42 firefighters from the Singapore Civil Defense Force (SCDF), the Singapore Civil Defense Agency is a Singaporean government agency whose main purpose is to provide assistance to extinguish fires, rescue missions and emergency medical treatment, as well as formulating, implementing and enforcing regulations on fire safety and also a place for civil protection.

c. Making canal blocking to maintain peatland moisture

Professional troops sent by the state of Singapore to help tackle forest and land fires in southern Sumatra, namely the SCDF Personnel, joined a team of firefighters from Indonesia and will extinguish forest and land fires in Sumatra South, especially in the Ogan Komering Ilir area and also Musi Banyuasin. One of the programs carried out by the forest and land firefighting team in South Sumatra is the creation of Canal Blocking, which, according to Indonesian president Joko Widodo, fires on peatlands are not very visible, because it could be that at the top of the peat there were no visible hotspots, but in the lower layer of the peat there are still flames, which is why the forest fire team made blocking canals to rewet the peat land even though the re-wetting process took a long time.

d. Monitoring the point of fire and doing normalization

The combined team of forest firefighters in South Sumatra also monitoring the fires, the firefighters were assigned to monitor whether the water bombing techniques carried out by aircraft and helicopters could completely extinguish forest and land fires that occurred at a hotspot, if indeed there is still a fire after a water bombing, the combined team of forest fires will extinguish the hotspot by using a water pump, a water pump that has been paired with a special water hose will spray clean water to the points of the fire that have not been completely extinguished.

It is hoped that routine monitoring and normalization at fire points will not only extinguish forest and peat fires in areas where the peat is burning, normalization will also make areas that were prone to fire become moist and difficult for fire to reappear.

\section{Conclusion}

Forest and land fires are not a disaster that can be underestimated if they are aware of the dangers that threaten, therefore it takes a very optimal effort in tackling the disaster of forest and land fires, and will be more optimal if there are more than one party trying extinguish the forest fires, like what Singapore did for Indonesia.

Singapore's assistance is inseparable from how
Singapore has its concern and sense of responsibility for the environmental damage that occurs, because if left alone will lead to a greater disaster namely global warming and global climate change, this can be proven by Singapore's engagement in the AATHP, the Kyoto Protocol and also the declaration of those who oppose global warming and climate change.

Forest and land fires have been so great in South Sumatra, with several individuals and groups declaring that this 2015 forest and land fire is the largest environmental crime in the 21 st century, with $2,611,411.44$ hectares of forest and land area in Indonesia burned, and 24 percent of forest and land fires in Indonesia originated from South Sumatra, the impact was huge, ranging from improving air quality to be worse in South Sumatra and Singapore, economic losses reaching 221 trillion rupiah, and also an increase in patients with ISPA disease.

The massive negative effect because of of forest and land fires in Indonesia is a separate call for friendly countries to help Indonesia in handling these forest and land fires, including Singapore with its commitment to fight environmental damage and global warming, by sending a helicopter with fire fighting equipment and Do not forget the Singaporean civilian army personnel, the process of extinguishing forest and land fires in South Sumatra to be slightly lighter.

\section{References}

[1] Notohadinegoro T. 2006. Pembakaran dan Kebakaran Lahan. Jurnal. Ilmu Tanah Universitas Gajah Mada, Yogyakarta.

[2] Fazar, M., \& Priyambodo, R. 2014. Kebakaran lahan di sejumlah wilayah ASEAN. Retrieved June 162019.

[3] Partono, S., Sonny Partono. 2014. kebakaran hutan dan lahan di indonesia dan upaya pengendaliannya, Jakarta: Kementrian Lingkungan Hidup dan Kehutanan. Jakarta: Kementrian Lingkungan Hidup dan Kehutanan.

[4] Sipongi. (n.d.). 2018. Rekapitulasi Luas Kebakaran Hutan dan Lahan (Ha) Per Provinsi Di Indonesia Tahun 2013-2018. Retrieved 2019.

[5] Biologi.co.id. 2019. Elnino: Pengertian, Dampak dan Proses Terjadinya Lengkap. Retrieved 2019.

[6] Adinugroho, W. C., Suryadiputra, I. N., Saharjo, B. H., \& Siboro, L. 2002. Manual for the Control of Fire in Peatlands and Peatland Forest. Retrieved 2019.

J., \& Pettiford, L. 2015. Hubungan Internasional Perspektif dan Tema, Yogyakarta: Pustaka Pelajar. 
[8] Rani, F. 2013. Perspektif Green Thought Dalam Paradigma Baru Politik Internasional (Teori Dan Praktek). Transnasional. Retrieved 2019, pp. 865-875.

[9] Wetlands International (n.d.). 2017. Kebakaran hutan dan lahan, Fire Prevention. Retrieved 2019.

[10] Yulianti, N., 2018. Pengenalan Bencana Kebakaran dan Kabut Asap Lintas Batas. Retrieved 2019.

[11] National Geographic Indonesia (n.d.). 2009. Pemanasan Global Terjadi Lebih Cepat, Ini Bahaya yang Menghantui Bumi. Retrieved July 102019.

[12] DW. 2015. One-meter rise in sea levels inevitable, NASA says. Retrieved 2019.

[13] Katadata.co.id. 2016. Kerugian Akibat Kebakaran Hutan $2015 \quad R p 221$ Triliun. Retrieved 2019.

[14] Purnama, I. 2015. BMKG: Kualitas Udara Palembang Tidak Sehat. Retrieved from Okezone News. Retrieved 2019.

[15] Saturi, S., \& Nugraha, I. 2015. 1,7 Juta Hektar Lahan Terbakar, Indonesia Mulai Terima Bantuan Negara Lain. Retrieved 2019.

[16] Aksi Cepat Tanggap. 2015. Begini Cara Pesawat Asing Bantu Padamkan Kabut Asap Sumatera. Retrieved 2019. 